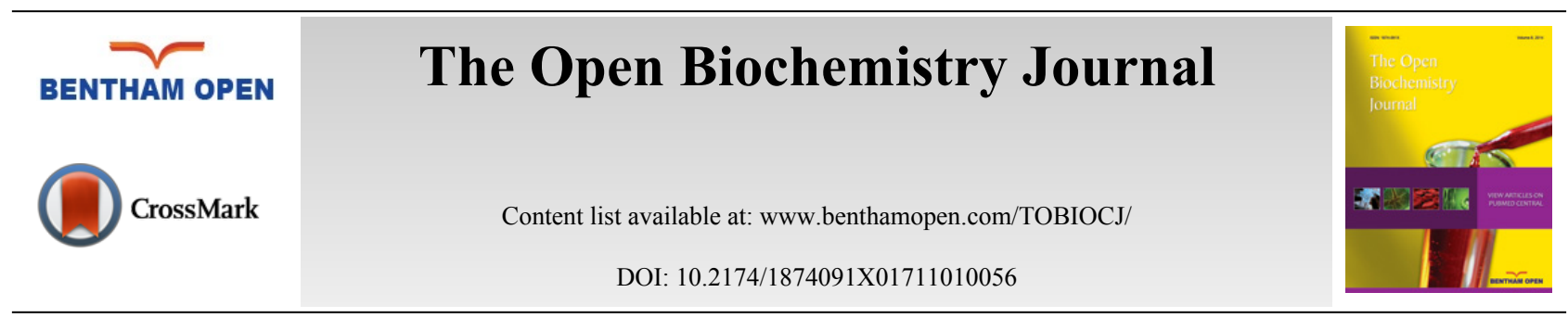

RESEARCH ARTICLE

\title{
Docosahexaenoic Acid Inhibits Vascular Smooth Muscle Cell Proliferation Induced by Glucose Variability
}

\author{
Kaliyaperumal Rani* and Nway Y. Aung \\ Nanyang Technological University Singapore, Singapore
}

Received: October 08, 2016

Revised: February 23, 2017

Accepted: March 17, 2017

\begin{abstract}
:
Background:

Vascular Smooth Muscle cells (VSMC) enact crucial roles in early vasculogenesis and sustenance of vascular integrity. However, aberrant proliferation of VSMC followed by migration into the blood vessel wall leads to the formation of vascular lesions accounting for the degeneration and remodelling of vascular basement membrane. In diabetes, hyperglycaemia accelerates VSMC proliferation and contributes to the initiation and progression of atherosclerotic lesions. Recently, acute glucose fluctuations have been implicated in the abnormal VSMC proliferation and complications of diabetic atherosclerosis. Docosahexaenoic acid (DHA), a $\omega-3$ polyunsaturated fatty acid (PUFA) has been shown to inhibit proliferation of several cell types implicating several different mechanisms. In the present study, we have investigated the effects of DHA on VSMC proliferation induced by stable and intermittent high glucose levels.
\end{abstract}

\section{Method:}

Confluent cultures of rat aortic VSMCs were treated with DHA for $24 \mathrm{hrs}$ and then exposed to stable high glucose $(25 \mathrm{mmol} / \mathrm{L}$, SHG) or intermittent high glucose $(5 \mathrm{mmol} / \mathrm{L}$ and $25 \mathrm{mmol} / \mathrm{L}$ alternating every $12 \mathrm{hrs}$, IHG) for 72 hrs. Cell proliferation was examined by the MTT viability assay, while apoptosis process was evaluated by the Hoechst staining, flow cytometry and caspase- 3 activity assays.

Results:

Our data demonstrated that the hyper proliferation induced by stable and intermittent high glucose levels was significantly inhibited by the DHA pre-treatment. DHA significantly increased caspase-3 activity, resulting in enhanced DNA fragmentation and apoptosis.

\section{Conclusion:}

Our results suggest that DHA reduced the high glucose-induced proliferation of VSMC and induced cell apoptosis.

Keywords: Apoptosis, Diabetic atherosclerosis, Docosahexaenoic acid, Intermittent high glucose, Proliferation, Stable high glucose, Vascular smooth muscle cells.

\section{INTRODUCTION}

Atheroscelerosis-associated macrovascular problems such as myocardial infarction and cerebrovascular diseases contribute to the major causes of morbidity and fatality in diabetic populations [1]. Hyperglycaemia hastens the progression of atherosclerotic lesions by elevating the atherogenic potency of vascular smooth muscle cells (VSMCs) in diabetes patients [2]. Aberrant VSMC proliferation along with its migration into the blood vessel wall leads to the formation of vascular lesions accounting for the degeneration and remodelling of vascular basement membrane [3, 4]. It

\footnotetext{
* Address correspondence to this author at the Nanyang Technological University Singapore, Singapore, Tel: +65141015; E-mails: kranimani@gmail.com; ksrani2006@gmail.com
} 
has been hypothesized that an imbalance between exaggerated proliferation and depressed apoptosis might be involved in abnormalities of VSMC growth associated with cardiac complications [5]. Therefore, restoring the delicate balance between VSMC proliferation and apoptosis may offer effective treatment strategy for diabetic atherosclerosis.

Chronic hyperglycaemia has been recognised as the primary causal factor for macrovascular complications preceding to accelerated atherosclerosis in diabetes. Both fasting and post prandial plasma sugar levels account for this process. Recently, acute glucose fluctuation in diabetes is identified as an additional factor that triggers the diabetes complications [6]. Hence, "hyperglycaemic vacillations" might be entitled with unambiguous and pivotal responsibility in the pathogenic diabetic vascular complications [7]. For instance, in human umbilical vein endothelial cells (HUVECs), intermittent high glucose (IHG) has been evinced to stimulate the overproduction of reactive oxygen species (ROS) and to contribute towards enhanced cellular apoptosis [8]. Previous studies indicated that IHG accelerated the number of malfunctional $\beta$ cells provoking apoptosis, a condition known as $\beta$ cell glucose toxicity [9, 10]. IHG induced a higher manifestation of adhesive molecules such as ICAM-1, VCAM-1 and E-selectin in HUVECs than that of stable high glucose (SHG) [11]. A recent study on VSMCs found that IHG accelerated cell proliferation and is facilitated by enhanced osteopondin (OPN) synthesis, a cell adhesion molecule that can bind with the VSMCs surface integrin receptor, and mediate cellular adhesion, proliferation and migration [6]. These findings demonstrate that the inconstancies of glucose level contribute directly to the vascular complications in diabetic population.

Salutary effects of foods, enriched with marine-derived $\omega-3$ polyunsaturated fatty acids (PUFA), in treating cardiovascular diseases are widely accepted. Epidemiology results also demonstrate that regular consumption of $\omega-3$ PUFAs helps in minimizing the fatality rate of cardiovascular diseases [12, 13]. In particular, a decline trend exhibited in atherosclerosis inflammatory pathology and the decreasing heart attack fatality rate of diabetes patients were associated with increased $\omega-3$ PUFA intake [14 - 16]. The defense mechanism through which $\omega-3$ PUFA functions remains obscure but are anticipated to be ascribable to their actions on endothelial and vascular smooth muscle cell functions [17]. For instance, docosahexaenoic acid (DHA), a $\omega-3$ PUFA, was found imperative in alternating the signal transduction mechanisms in various cell types [18, 19]. DHA has also been identified in conducting anti-tumorigenic pathway correlated with inhibition of tumor-mediated angiogenesis [20, 21]. In human endothelial cells, DHA was reported to protect the cells from stress-induced apoptosis [22]. In VSMCs, DHA influences vascular remodeling and restenosis [23]. In the present study, we investigated the effects of DHA against the exhilarated proliferation of rat VSMCs exposed to SHG or IHG in culture.

\section{MATERIALS AND METHOD}

\subsection{Materials}

Dulbecco's modified Eagle's medium (DMEM), penicillin, streptomycin, trypsin, dimethyl sulfoxide (DMSO) and foetal bovine serum were purchased from Gibco, Singapore. 3-(4, 5-dimethylthialzal-z-yl)-2,5-diphenylterazolium bromide (MTT), Hoechst 33258 dye and DHA (22:6n-3) were procured from Sigma-Aldrich (Singapore). Caspase-3 Fluorescence Assay kit was from Cayman chemicals (Michigan, USA). The other reagents were all from Sigma Chemical Co (Singapore). DHA was dissolved in $99.5 \%$ ethanol and stocked as aliquots at $-80^{\circ} \mathrm{C}$. As DHA is highly susceptible to oxidation, every aliquot was used not more than two times.

\subsection{Cell Culture}

Rat aortic VSMC purchased from American Type Culture Collection (ATCC, Manassas, USA) was used for this study. Cells were cultured in DMEM consisting of $5.5 \mathrm{mmol} / \mathrm{L}$ glucose, $10 \%$ fetal bovine serum, $100 \mathrm{U} / \mathrm{ml} \mathrm{penicillin}$ and $100 \mathrm{U} / \mathrm{ml}$ streptomycin at $37^{\circ} \mathrm{C}$ (humidified atmosphere with $5 \% \mathrm{CO} 2$ ). Cells at passages $7-9$ were used for the experiments.

\subsection{Experimental Procedures}

VSMCs were trypsinized into cell suspension and seeded in each well of 96-well plate with density of $10^{4}$ cells per well. When the cells became confluence (70-80\%), serum-free DMEM was used to replace the medium and cells were allowed to synchronize for $24 \mathrm{hrs}$. Synchronized cells were then split into eight different categories: normal control group (Con), SHG group, IHG group, DHA control group (DHA-Con), DHA-SHG group, DHA-IHG group and osmotic control groups (OS1 and OS2). In the Con group, cells were exposed to normal concentration of glucose $(5.5 \mathrm{mmol} / \mathrm{L})$. The cells in SHG group were treated with stable high concentration of glucose $(25 \mathrm{mmol} / \mathrm{L}) \mathrm{whereas}$ 
those in IHG group, they were treated with intermittent concentrations (fluctuating between $5.5 \mathrm{mmol} / \mathrm{L}$ and $25 \mathrm{mmol} / \mathrm{L}$ within $12 \mathrm{hrs}$ ) and were incubated for $72 \mathrm{hrs}$. In DHA-SHG group, the cells were pretreated with $20 \mu \mathrm{M}$ DHA and exposed to stable glucose whereas in DHA-IHG group, the cells were pretreated with $20 \mu \mathrm{M}$ DHA and exposed to intermittent concentrations of glucose for indicated period. The cells in DHA-Con group were incubated with identical amount of DHA without any further treatment. Among the two osmotic controls, one was treated with mannitol (44.4 $\mathrm{mM})$ plus normal glucose $(5.5 \mathrm{mmol} / \mathrm{L})$ as a common high osmotic control; the other represents an intermittent high osmotic control (alternating between $5.5 \mathrm{mmol} / \mathrm{L}$ glucose or mixture of mannitol and $5.5 \mathrm{mmol} / \mathrm{L}$ glucose every $12 \mathrm{hrs}$ ). Equal quantities of ethanol were used to incubate the control groups and the concentration in the medium was maintained at less than $0.1 \%$. Cells in all different categories were treated under identical conditions and all experiments were conducted three times at least.

\subsection{Cell Proliferation Assay}

Cell proliferation was evaluated by estimating the metabolism of 3-(4, 5-dimethyldiazol-2-yl)-2, 5diphenyltetrazolium bromide (MTT). In brief, VSMCs seeded in 96-well microtiter plates were pretreated with $20 \mu \mathrm{M}$ DHA and exposed to either constant or intermittent high glucose for $72 \mathrm{hrs}$. After the treatment, $20 \mu \mathrm{L}$ of MTT solution $(5 \mathrm{mg} / \mathrm{mL})$ was mixed in all the wells and cells were incubated at $37^{\circ} \mathrm{C}$ for another $4 \mathrm{hrs}$. The solution was disposed of and $150 \mu \mathrm{L}$ of solubilisation solution (DMSO) was added into each well followed by 10 mins shaking. Absorbance of the solubilised blue formazin dye was read at $570 \mathrm{~nm}$ using a microplate reader. Cell viability was represented as a percentage of cytoprotection versus control group, fixed at $100 \%$.

\subsection{Morphological Analysis by Hoechst 33258}

For morphological evaluation of nuclei, VSMCs were stained using nuclear dye Hoechst 33258 . Hoechst 33258 fluorochromes have been used to define the nuclear morphological features that act as a quantitative index of apoptosis in vast majority of cell culture systems [24, 25]. After treatment, cells were stained with Hoechst $33258(10 \mu \mathrm{g} / \mathrm{mL})$ at room temperature in the dark for 30 mins and washed three times with PBS. Finally, cells were illuminated with ultraviolet light and nuclear morphological transformations, such as condensed and disintegrated nuclei with intense bright fluorescence, were visualized under fluorescence microscopy.

\subsection{Apoptosis Analysis by Flow Cytometry}

Apoptosis was estimated quantitatively through the analysis of propidium iodide (PI) staining in flow cytometry. In brief, VSMC grown in $25 \mathrm{~cm}^{2}$ culture flasks, after being treated with glucose, were harvested by trypsin and washed with PBS. Cells were then fixed with $70 \%$ ice cold ethanol at $4{ }^{\circ} \mathrm{C}$ overnight. Next day, cells were washed twice with cold PBS followed by incubation with $100 \mu \mathrm{g} / \mathrm{ml}$ RNase at $37^{\circ} \mathrm{C}$ for $20 \mathrm{mins}$. After that, cells were centrifuged (10 min, $1800 \mathrm{rpm}$ at room temperature) and the pellets were subjected to incubation with PBS containing $50 \mu \mathrm{g} / \mathrm{ml} \mathrm{PI} \mathrm{at} 37^{\circ} \mathrm{C}$ in the dark for 30 mins. Samples were analysed using flow cytometer (Becton Dickinson FACScan) and flowing software.

\subsection{Caspase Activity Assay}

Caspase 3 activity was assessed through monitoring the fluorescence of $\mathrm{t}$ N-Ac-DEVD-N'-MC-R110 substrate with respect to the manufacturer's instructions (Cayman Chemical, USA). VSMCs seeded in 96-well plate were treated as described above, and the cell lysates were prepared by adding $100 \mu$ cell lysis buffer (Cayman Chemical) followed by shaking for $30 \mathrm{~min}$ at room temperature. After centrifugation at $800 \mathrm{xg}$ for $10 \mathrm{~min}, 100 \mu \mathrm{l}$ of supernatant was shifted to another plate followed by incubation at $37^{\circ} \mathrm{C}$ with $100 \mu \mathrm{l}$ of N-Ac-DEVD-N'-MC-R110, a caspase 3 substrate. Fluorescence of the cleaved substrate was measured at an excitation wavelength at $485 \mathrm{~nm}$ and an emission wavelength at $535 \mathrm{~nm}$ using a microplate reader.

\subsection{Data Analysis and Statistics}

Paired student's t-test was used to analyse the data obtained. Discrepancies of $\mathrm{p}$ values less than 0.05 were taken as statistically significant and the results were expressed as mean \pm standard deviation (SD) attained from at least three experiments. 


\section{RESULTS}

\subsection{Effect of DHA on Proliferation of VSMCS Induced by IHG}

It is known that IHG is more detrimental than SHG in hastening abnormal proliferation of VSMCs in diabetes [6, 26]. To test whether DHA modifies IHG-induced proliferation of VSMCs, quiescent cultures were pretreated with DHA and exposed to constant or intermittent high glucose concentrations for $72 \mathrm{hrs}$. After treatment, cell viability was measured using the MTT reduction assay.

As depicted in Fig. (1), cell viability of the Con group was fixed at 100\%. The cell viability of VSMCs exposed to SHG was significantly increased to $160.35 \pm 1.88 \%(\mathrm{p}<0.001)$ of the Con value. Furthermore, IHG was found to induce significant increase in cell viability more than SHG $(192.25 \pm 1.71 \%, \mathrm{p}<0.001)$. Pre-treatment of cells with DHA reduced the cell viability to $107.31 \pm 4.21 \%(\mathrm{p}<0.001)$ in DHA-SHG group and to $108.93 \pm 6.74 \%(\mathrm{p}<0.001)$ in DHAIHG treated group. However, the Con groups pre-treated with DHA did not show any significant difference in cell viability. Also, there was no substantial discrepancy in the cell viability noted among the mannitol-treated and control group. These results indicated that the VSMCs exposed to IHG showed increased cell proliferation than SHG and pretreatment with DHA significantly attenuated the induced proliferation in both SHG and IHG group.

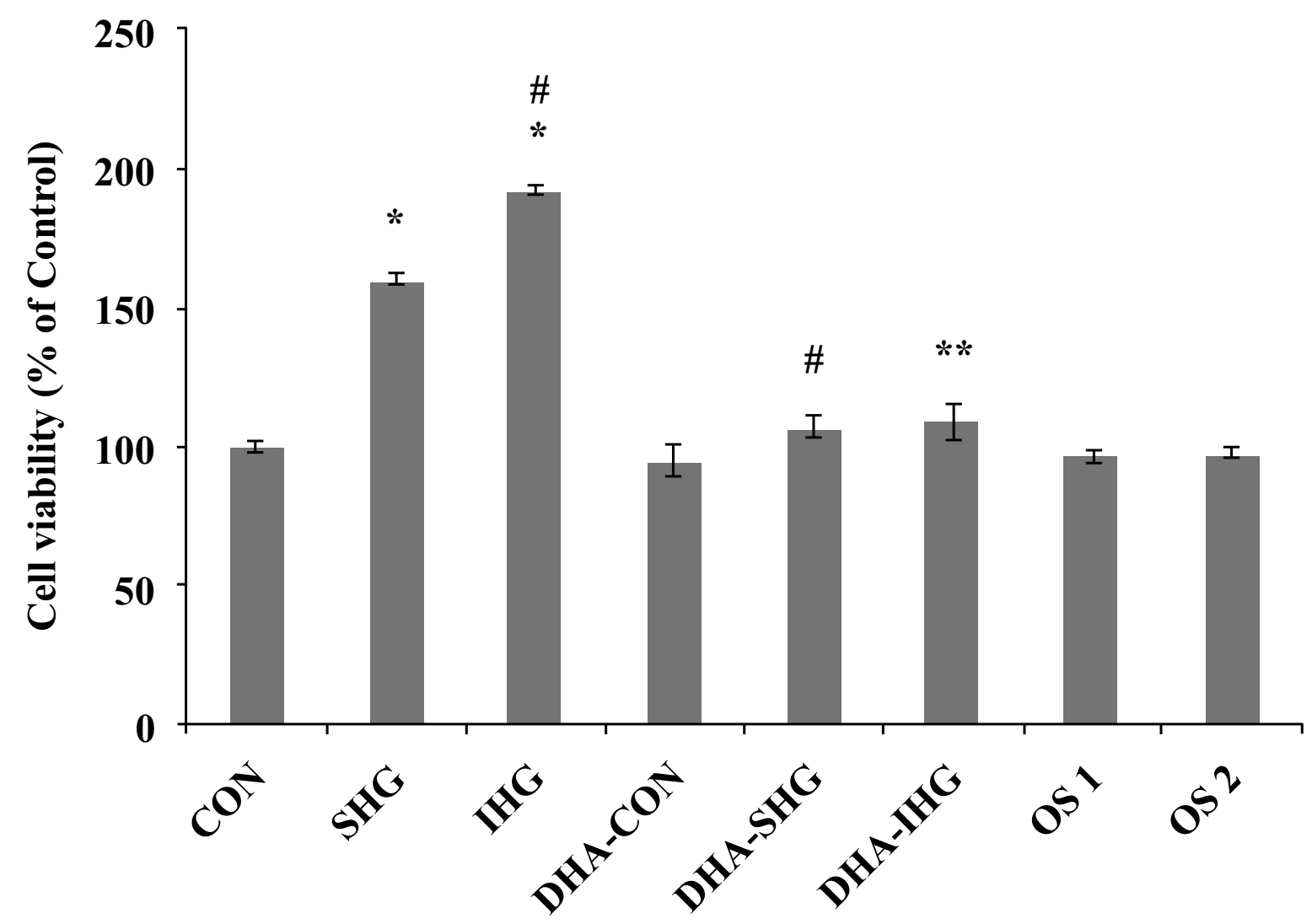

Fig. (1). Effect of DHA on the proliferation of VSMCs induced by IHG. Quiescent cultures of VSMC were pretreated with DHA and exposed to constant or intermittent high glucose level for $72 \mathrm{hrs}$. After treatment, cell survival was examined using the MTT reduction assay. Cell viability was calculated as the percentage of the control group. The data represent mean \pm SEM of 3 individual experiments. ${ }^{*} P<0.001$ versus Con, $\# P<0.001$ versus $\mathrm{SHG}, * * P<0.001$ versus $\mathrm{IHG}$.

\subsection{Effects of DHA on Nuclear Morphology of VSMCS Exposed to IHG}

Cell proliferation and apoptosis represent two different cellular events, however, they are often found intimately connected under physiological conditions. As reported by previous studies, any factor which restrains the viability of cell could suscitate the apoptosis of that cell or vice versa [27]. The effects of DHA on apoptotic index of VSMCs treated with HG was assessed by monitoring apoptotic morphological differentiations using bis-benzimide (Hoechst 33258) staining under a fluorescent microscope. 
As illustrated in Fig. (2), the nuclei of Con cells contained evenly dispersed chromatin with sparse fluorescence signal showing almost no signs of morphological nuclear damage. Cells exposed to SHG and IHG also exhibited no chromatin disintegration or margination. In marked contrast, DHA treatment in SHG and IHG group demonstrated enhanced DNA fragmentation and condensation. However, treatment with mannitol did not instigate the apoptosis of VSMCs in both control groups.
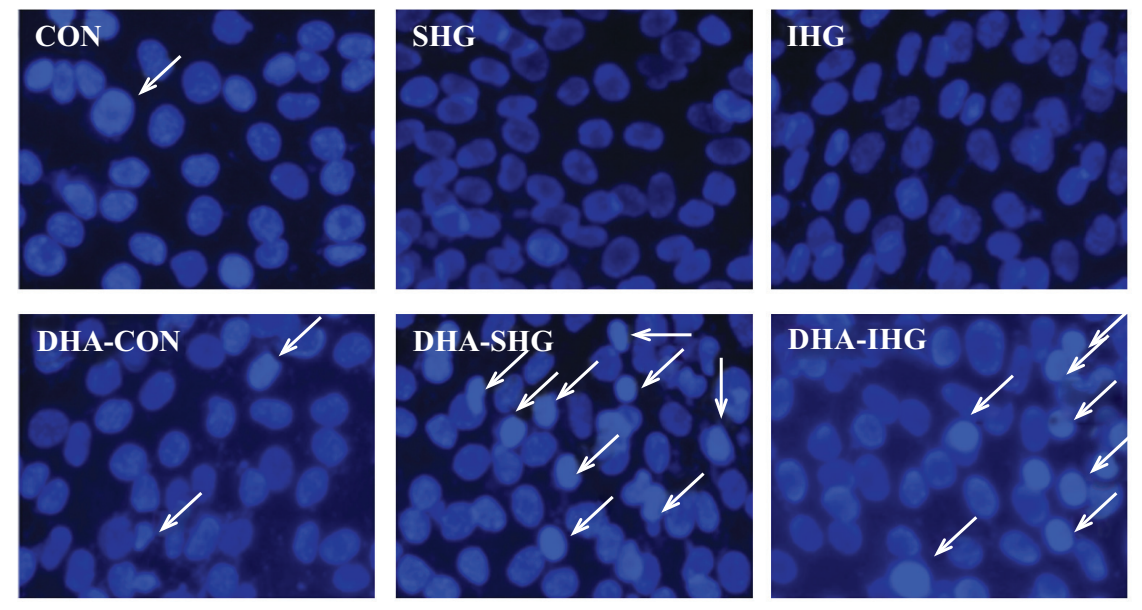
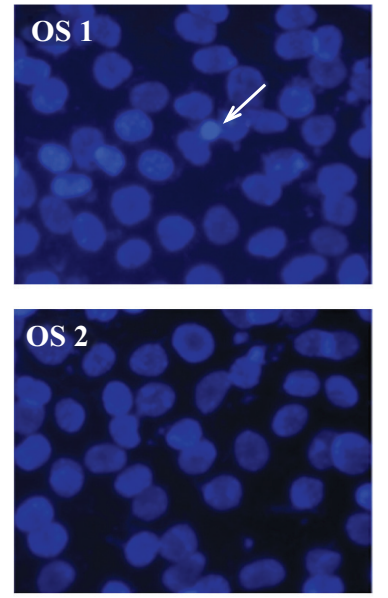

Fig. (2). Effects of DHA on the nuclear morphology of HG-treated VSM cells stained with Hoechst 33258. The Con group showed cells with uniformly dispersed chromatin and weak fluorescence signals. DHA-treated SHG and IHG group demonstrated hypercondensed chromatin with increased number of apoptotic cells.

The above results revealed that DHA treatment could result in increase of apoptotic cells in both SHG and IHG groups, further affirming that DHA induced cell death through apoptosis.

\subsection{DHA Pre-treatment Induces Apoptosis of VSMCS Exposed to IHG Measured by Flow Cytometry}

To quantitatively gain insight into the effect of DHA on apoptosis of VSMCs exposed to IHG, the apoptosis rate of VSMCs was computed by FACS assay using PI staining (Fig. 3a). As shown in Fig. (3b), Con group revealed lower apoptosis rate of $6.62 \pm 1.48 \%$. Similarly SHG and IHG groups also showed reduced percentage of apoptotic cells. On the contrary, DHA treatment in SHG and IHG group triggered significant elevations of apoptosis with the apoptosis rate of $31.54 \pm 1.39 \%$ and $39.89 \pm 5.39 \%$ respectively. However, mannitol treatment did not show any changes in both control groups.

\subsection{DHA Pre-Treatment Induces Caspase-3 Activity in IHG Treated VSMC}

Cell apoptotic events, triggered by a diverse array of stimuli, focalize on the stimulation of caspase family, premier among which is caspase-3. Caspase- 3 enacts an inevitable role in turning on the apoptotic processes in a wide range of cell types including smooth muscle cells [28]. In order to investigate whether DHA mediates its apoptotic effects through caspase-3, caspase-3 activity in VSMC was assessed after being exposed to SHG and IHG. The results revealed that high glucose treatment in both cases did not affect the basal caspase-3 activity when compared to the control Fig. (4). Besides, mannitol treatment in both osmotic control groups did not influence the basal caspase-3 activity. However, addition of DHA resulted in a 2.95-fold raise in caspase-3 activity in the SHG group $(P<0.001)$ and a 3.65 fold increase in the IHG group $(\mathrm{p}<0.001)$, while no significant effects in the Con group could be shown.

\section{DISCUSSION}

Herein, we reported a novel finding that DHA inhibited the proliferation of rat aortic VSMCs induced by SHG and IHG. Persistent hyperglycaemia has been shown to stimulate the proliferation of VSMCs and to contribute towards the advancement of diabetic atherosclerosis [29 - 32]. Recent evidences demonstrated that intermittent hyperglycaemia also executes its influence on expedition of diabetic atherosclerosis supporting a pathophysiologic relationship between IHG and enhanced cardiovascular susceptibility in diabetes [33 - 35]. Also, it has been hypothesised that variability in glycaemic control might be even destructive to the VSMCs as compared to stable high glucose concentration [6]. Therefore, intermittent hyperglycaemia may act as an additional causative factor in the development of diabetic 
atherosclerotic complications. New therapies targeting acute glucose fluctuations thus represent a potential therapeutic approach to prevent or improve these conditions.

(a)
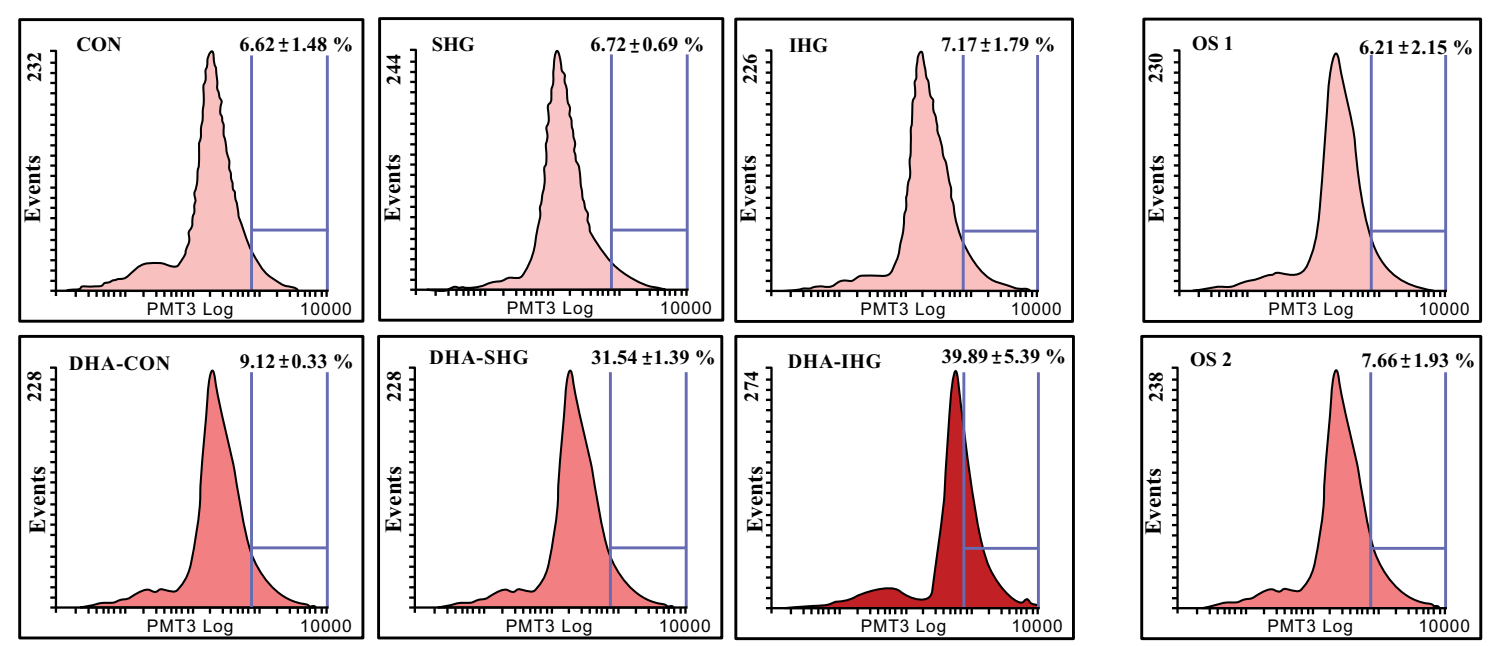

(b)

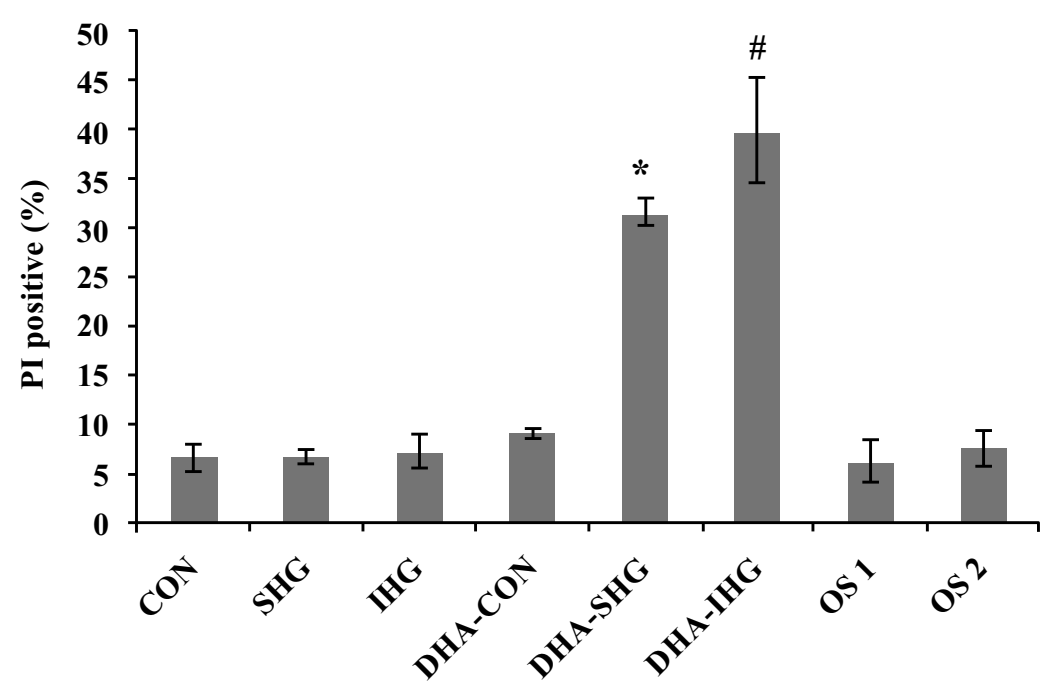

Fig. (3). Effects of DHA pretreatment on apoptosis of VSMCs characterised by flow cytometry. (a) VSMCs were pretreated with DHA for $24 \mathrm{hrs}$ and exposed to stable or intermittent high glucose for $72 \mathrm{hrs}$ as mentioned in the text. The apoptosis rate of VSMCs was computed by FACS assay using PI staining. Results from 10,000 events were analyzed in each sample. (b) Quantitative analysis of apoptosis. Data were expressed as mean $\pm \mathrm{SD}$ from three experiments. The percentages of apoptotic cells in DHA-SHG and DHAIHG were increased significantly. ${ }^{*} P<0.001$ versus SHG, $\# P<0.001$ versus IHG.

Previous studies investigated the potency of $\omega-3$ and $\omega-6$ PUFAs in suppressing tumour progression and demonstrated that DHA potently suppresses cancer cell growth, suggesting the influence of $\omega-3$ PUFA in modulating cancer progression [36, 37]. DHA is also shown to increase apoptotic cell death in normal rat colonic cells [38, 39]. In proliferating human endothelial cells, DHA has been demonstrated to exert anti-angiogenic effects by inducing apoptosis [40]. In the present study, the inhibitory effect of DHA on HG-influenced proliferation of VSMC was established by MTT assay which demonstrated that DHA could inhibit VSMCs proliferation induced by HG and IHG. 


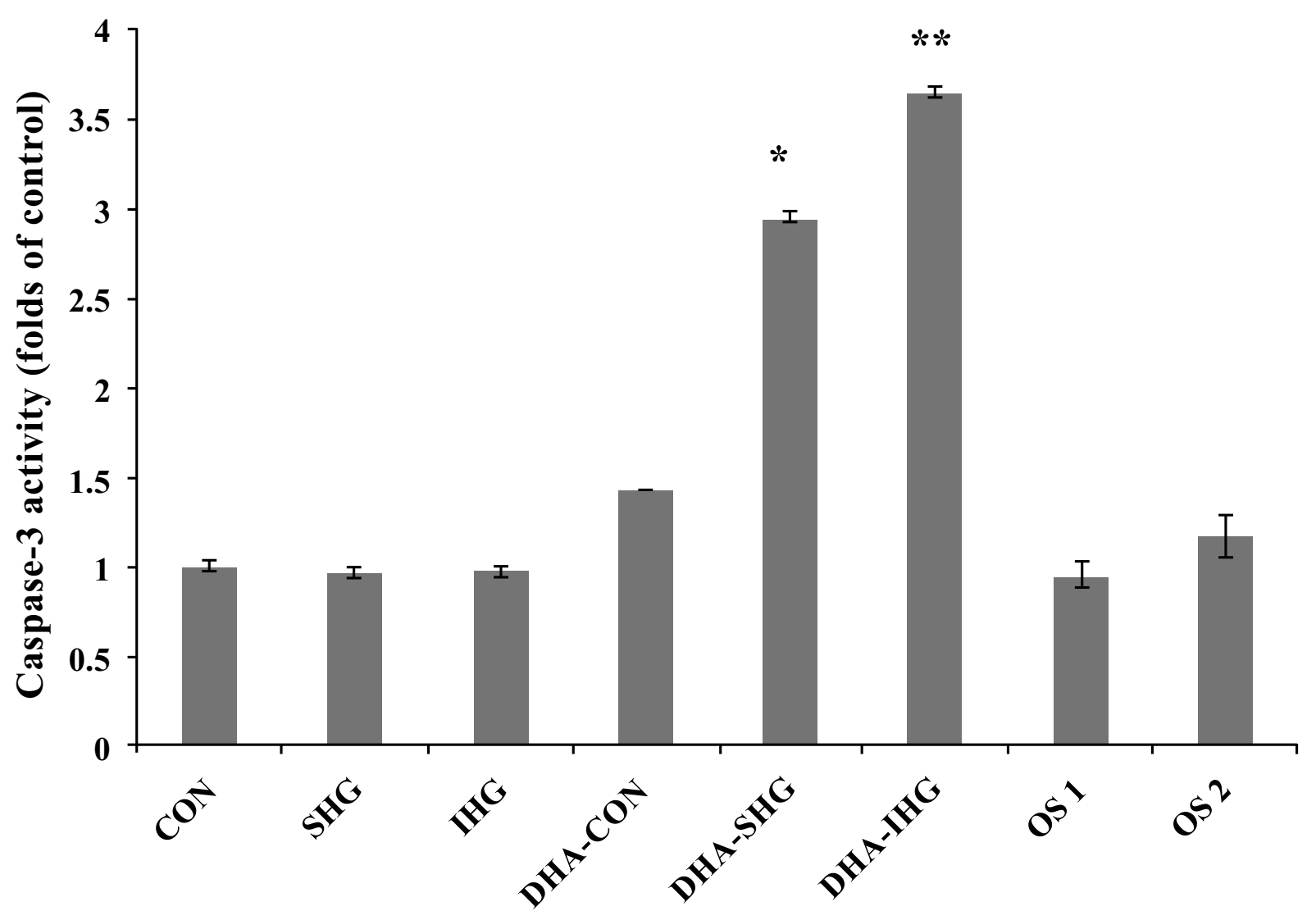

Fig. (4). Effects of DHA pre-treatment on caspase-3 activity in HG-treated VSMC. The VSMCs seeded in a 96-well plate were treated as described in the Methods section. The caspase 3 activity was examined by measuring the fluorescence of the N-Ac-DEVDN'-MC-R110 substrate in the plate reader with an excitation wavelength at $485 \mathrm{~nm}$ and an emission wavelength at $535 \mathrm{~nm}$. Data represents mean $\pm \mathrm{SD}$ of 3 individual experiments with $* P<0.001$ versus SHG, ${ }^{* *} P<0.001$ versus IHG.

Apoptosis enacts an inevitable role in both normal physiology and pathology in a variety of tissues [41]. Chromatin condensation is one of the prominent hallmarks of apoptotic cell death, which is brought about by activated caspases. In the present study, the results of Hoechst 33258 staining demonstrated that DHA treatment on VSMCs exposed to SHG or IHG could induce DNA fragmentation and nuclear chromatin hypercondensation. Also, flow cytometric analysis of PI staining provided the quantitative index of apoptosis induced by DHA-pretreatment in cells exposed to SHG and IHG. To further investigate the apoptosis pathway, caspase-3 activity was evaluated. Apoptotic process is activated via two main mechanisms; one involving death receptors and another one involving stress mediated activation of caspase-9. Eventually these two mechanisms synchronize to elicit caspase-3 activation. Hence, caspase-3 (also referred as CPP32/Yama) is considered as the primary executioner in the initiation of apoptosis [42]. In the present study, DHA pre-treatment significantly induced caspase-3 activity in VSMCs which illustrates an apoptotic effect of DHA in this cell system. Elevated caspase-3 activity along with an upsurge of apoptotic cells revealed that caspase-3 induce apoptosis associated signalling cascade with genetic expression resulting in the development of apoptosis. The control cells treated with DHA did not show any obvious signs of apoptosis and elevated caspase-3 activity, which suggests that DHA induced caspase-3 activity and apoptosis predominantly in HG-induced hyper proliferating cultures of VSMCs.

The molecular mechanism through which DHA may induce apoptosis in smooth muscle cells is poorly understood. Previous studies indicated that DHA activated apoptosis through disruption of mitochondrial transmembrane potential, transformation of plasma membrane phosphatidyl serine, escalated bax expression and activation of caspase-3 [43]. Our findings revealed that DHA repressed the stimulatory effects of HG and IHG on the proliferation of cultured VSMCs by inducing apoptosis. Also, the present data suggested that the inhibitory effect of DHA on HG induced VSMC proliferation was at least partially mediated by caspase 3 . However, the current study did not fully investigate the molecular mechanism behind the apoptotic effect of DHA on VSMCs under HG conditions, and also the possible involvement of other caspases, which we plan to investigate in the future. 


\section{CONCLUSION}

In summary, it was found that pre-treatment of VSMCs with DHA inhibits the proliferation of VSMCs triggered by HG level. In addition to the stable high glucose, protective effects of DHA were also pronounced in cells exposed to IHG, indicating the protective role of DHA against vacillating hyperglycaemic states of diabetes. Results obtained in the present investigation indicate that apoptosis is most likely to be the essential mechanism through which DHA intercedes its anti-proliferative effects in VSMCs under HG conditions. Distinctive features of apoptosis such as chromatin condensation and nuclear fragmentation were clearly apparent in DHA-treated HG cells shown by the fluorescent microscopic images. Our results further suggested that the apoptotic role of DHA involves caspase-3 activation. Our results revealed a novel function of DHA in the restoration of healthy balance between VSMC proliferation and apoptosis, demonstrating a potential strategy for the treatment of HG fluctuations induced diabetic atherosclerosis complications. Future studies would focus on further investigation of evaluating the molecular signalling mechanism involved in these apoptotic pathways.

\section{LIST OF ABBREVIATIONS}

$\begin{array}{lll}\text { DHA- } & = & \text { Docosahexaenoic Acid } \\ \text { HG- } & = & \text { High Glucose } \\ \text { IHG- } & = & \text { Intermittent High Glucose } \\ \text { MTT } & = & -3-(4,5-\text { dimethyldiazol-2-yl })-2,5-\text { diphenyltetrazolium bromide. } \\ \text { PUFA - } & = & \text { Polyunsaturated Fatty Acid(s) } \\ \text { SHG- } & = & \text { Vascular Smooth Muscle Cells }\end{array}$

\section{CONFLICT OF INTEREST}

The author (editor) declares no conflict of interest, financial or otherwise.

\section{ACKNOWLEDGEMENTS}

The authors of the manuscript wish to express their thanks to Prof. Bjoern Neu, Prof. Kang Yuejun and Prof. Song Hoa for their support and encouragement and to Dr. Jacqueline Elena Lessig and Dr. Meghali Bora for their valuable comments.

\section{REFERENCES}

[1] Bell, D.S. Heart failure: the frequent, forgotten, and often fatal complication of diabetes. Diabet. Care, 2003, 26(8), 2433-2441. [http://dx.doi.org/10.2337/diacare.26.8.2433] [PMID: 12882875]

[2] Beckman, J.A.; Creager, M.A.; Libby, P. Diabetes and atherosclerosis: epidemiology, pathophysiology, and management. JAMA, 2002, 287(19), 2570-2581.

[http://dx.doi.org/10.1001/jama.287.19.2570] [PMID: 12020339]

[3] Massi-Benedetti, M.; Federici, M.O. Cardiovascular risk factors in type 2 diabetes: the role of hyperglycaemia. Exp. Clin. Endocrinol. Diabetes, 1999, 107(Suppl. 4), S120-S123. [http://dx.doi.org/10.1055/s-0029-1212165] [PMID: 10522835]

[4] Srivastava, A.K. High glucose-induced activation of protein kinase signaling pathways in vascular smooth muscle cells: a potential role in the pathogenesis of vascular dysfunction in diabetes (review). Int. J. Mol. Med., 2002, 9(1), 85-89. [review]. [PMID: 11745003]

[5] Hamet, P. Proliferation and apoptosis of vascular smooth muscle in hypertension. Curr. Opin. Nephrol. Hypertens., 1995, 4(1), 1-7. [http://dx.doi.org/10.1097/00041552-199501000-00001] [PMID: 7743153]

[6] Sun, J.; Xu, Y.; Dai, Z.; Sun, Y. Intermittent high glucose enhances proliferation of vascular smooth muscle cells by upregulating osteopontin. Mol. Cell. Endocrinol., 2009, 313(1-2), 64-69.

[http://dx.doi.org/10.1016/j.mce.2009.08.019] [PMID: 19723557]

[7] Ceriello, A. The emerging role of post-prandial hyperglycaemic spikes in the pathogenesis of diabetic complications. Diabet. Medi. : J. Brit. Diabet. Assoc., 1998, 15, 188-193.

[8] Quagliaro, L.; Piconi, L.; Assaloni, R.; Martinelli, L.; Motz, E.; Ceriello, A. Intermittent high glucose enhances apoptosis related to oxidative stress in human umbilical vein endothelial cells: the role of protein kinase C and NAD(P)H-oxidase activation. Diabetes, 2003, 52(11), 2795-2804.

[http://dx.doi.org/10.2337/diabetes.52.11.2795] [PMID: 14578299] 
[9] Robertson, R.P.; Harmon, J.; Tran, P.O.; Poitout, V. Beta-cell glucose toxicity, lipotoxicity, and chronic oxidative stress in type 2 diabetes. Diabetes, 2004, 53(Suppl. 1), S119-S124. [http://dx.doi.org/10.2337/diabetes.53.2007.S119] [PMID: 14749276]

[10] Shi, X.L.; Ren, Y.Z.; Wu, J. Intermittent high glucose enhances apoptosis in INS-1 cells. Exp. Diabetes Res., $2011,2011,754673$.

[11] Quagliaro, L.; Piconi, L.; Assaloni, R.; Da Ros, R.; Maier, A.; Zuodar, G.; Ceriello, A. Intermittent high glucose enhances ICAM-1, VCAM-1 and E-selectin expression in human umbilical vein endothelial cells in culture: the distinct role of protein kinase $\mathrm{C}$ and mitochondrial superoxide production. Atherosclerosis, 2005, 183(2), 259-267. [http://dx.doi.org/10.1016/j.atherosclerosis.2005.03.015] [PMID: 16285992]

[12] Daviglus, M.L.; Stamler, J.; Orencia, A.J.; Dyer, A.R.; Liu, K.; Greenland, P.; Walsh, M.K.; Morris, D.; Shekelle, R.B. Fish consumption and the 30-year risk of fatal myocardial infarction. N. Engl. J. Med., 1997, 336(15), 1046-1053. [http://dx.doi.org/10.1056/NEJM199704103361502] [PMID: 9091800]

[13] Kromhout, D.; Bosschieter, E.B.; de Lezenne Coulander, C. The inverse relation between fish consumption and 20-year mortality from coronary heart disease. N. Engl. J. Med., 1985, 312(19), 1205-1209. [http://dx.doi.org/10.1056/NEJM198505093121901] [PMID: 3990713]

[14] He, K.; Song, Y.; Daviglus, M.L.; Liu, K.; Van Horn, L.; Dyer, A.R.; Greenland, P. Accumulated evidence on fish consumption and coronary heart disease mortality: a meta-analysis of cohort studies. Circulation, 2004, 109(22), 2705-2711. [http://dx.doi.org/10.1161/01.CIR.0000132503.19410.6B] [PMID: 15184295]

[15] Schmidt, E.B.; Arnesen, H.; de Caterina, R.; Rasmussen, L.H.; Kristensen, S.D. Marine n-3 polyunsaturated fatty acids and coronary heart disease. Part I. Background, epidemiology, animal data, effects on risk factors and safety. Thromb. Res., 2005, 115(3), 163-170. [http://dx.doi.org/10.1016/j.thromres.2004.09.006] [PMID: 15617737]

[16] Erkkilä, A.T.; Lichtenstein, A.H.; Mozaffarian, D.; Herrington, D.M. Fish intake is associated with a reduced progression of coronary artery atherosclerosis in postmenopausal women with coronary artery disease. Am. J. Clin. Nutr., 2004, 80(3), 626-632. [PMID: 15321802]

[17] Hirafuji, M.; Machida, T.; Hamaue, N.; Minami, M. Cardiovascular protective effects of n-3 polyunsaturated fatty acids with special emphasis on docosahexaenoic acid. J. Pharmacol. Sci., 2003, 92(4), 308-316. [http://dx.doi.org/10.1254/jphs.92.308] [PMID: 12939515]

[18] Denys, A.; Hichami, A.; Khan, N.A. Eicosapentaenoic acid and docosahexaenoic acid modulate MAP kinase enzyme activity in human Tcells. Mol. Cell. Biochem., 2002, 232(1-2), 143-148.

[http://dx.doi.org/10.1023/A:1014806122510] [PMID: 12030372]

[19] Denys, A.; Hichami, A.; Khan, N.A. n-3 PUFAs modulate T-cell activation via protein kinase C-alpha and -epsilon and the NF-kappaB signaling pathway. J. Lipid Res., 2005, 46(4), 752-758. [http://dx.doi.org/10.1194/jlr.M400444-JLR200] [PMID: 15627650]

[20] Larsson, S.C.; Kumlin, M.; Ingelman-Sundberg, M.; Wolk, A. Dietary long-chain n-3 fatty acids for the prevention of cancer: a review of potential mechanisms. Am. J. Clin. Nutr., 2004, 79(6), 935-945. [PMID: 15159222]

[21] Rose, D.P.; Connolly, J.M. Antiangiogenicity of docosahexaenoic acid and its role in the suppression of breast cancer cell growth in nude mice. Int. J. Oncol., 1999, 15(5), 1011-1015.

[PMID: 10536186]

[22] Pfrommer, C.A.; Erl, W.; Weber, P.C. Docosahexaenoic acid induces ciap1 mRNA and protects human endothelial cells from stress-induced apoptosis. Am. J. Physiol. Heart Circ. Physiol., 2006, 290(6), H2178-H2186. [http://dx.doi.org/10.1152/ajpheart.00933.2005] [PMID: 16473961]

[23] Walsh, K.; Smith, R.C.; Kim, H.S. Vascular cell apoptosis in remodeling, restenosis, and plaque rupture. Circ. Res., 2000, 87(3), 184-188. [http://dx.doi.org/10.1161/01.RES.87.3.184] [PMID: 10926867]

[24] Haimovitz-Friedman, A.; Cordon-Cardo, C.; Bayoumy, S.; Garzotto, M.; McLoughlin, M.; Gallily, R.; Edwards, C.K., III; Schuchman, E.H.; Fuks, Z.; Kolesnick, R. Lipopolysaccharide induces disseminated endothelial apoptosis requiring ceramide generation. J. Exp. Med., 1997, 186(11), 1831-1841. [http://dx.doi.org/10.1084/jem.186.11.1831] [PMID: 9382882]

[25] Wilson, I.; Gillinov, A.M.; Curtis, W.E.; Di Natale, J.; Burch, R.M.; Gardner, T.J.; Cameron, D.E. Inhibition of neutrophil adherence improves postischemic ventricular performance of the neonatal heart. Circulation, 1993, 88(5 Pt 2), II372-II379. [PMID: 8222181]

[26] Andrés, V.; Castro, C. Antiproliferative strategies for the treatment of vascular proliferative disease. Curr. Vasc. Pharmacol., 2003, 1(1), 85-98.

[http://dx.doi.org/10.2174/1570161033386763] [PMID: 15320855]

[27] Cheng, B.; Song, J.; Zou, Y.; Wang, Q.; Lei, Y.; Zhu, C.; Hu, C. Responses of vascular smooth muscle cells to estrogen are dependent on balance between ERK and p38 MAPK pathway activities. Int. J. Cardiol., 2009, 134(3), 356-365. [http://dx.doi.org/10.1016/j.ijcard.2008.02.017] [PMID: 18584900]

[28] Pan, S.L.; Guh, J.H.; Chang, Y.L.; Kuo, S.C.; Lee, F.Y.; Teng, C.M. YC-1 prevents sodium nitroprusside-mediated apoptosis in vascular 
smooth muscle cells. Cardiovasc. Res., 2004, 61(1), 152-158.

[http://dx.doi.org/10.1016/j.cardiores.2003.09.013] [PMID: 14732212]

[29] Kawamura, H.; Yokote, K.; Asaumi, S.; Kobayashi, K.; Fujimoto, M.; Maezawa, Y.; Saito, Y.; Mori, S. High glucose-induced upregulation of osteopontin is mediated via Rho/Rho kinase pathway in cultured rat aortic smooth muscle cells. Arterioscler. Thromb. Vasc. Biol., 2004, 24(2), 276-281.

[http://dx.doi.org/10.1161/01.ATV.0000112012.33770.2a] [PMID: 14670931]

[30] Krolewski, A.S.; Warram, J.H.; Valsania, P.; Martin, B.C.; Laffel, L.M.; Christlieb, A.R. Evolving natural history of coronary artery disease in diabetes mellitus. Am. J. Med., 1991, 90(2A), 56S-61S. [http://dx.doi.org/10.1016/0002-9343(91)90040-5] [PMID: 1994719]

[31] Sodhi, C.P.; Phadke, S.A.; Batlle, D.; Sahai, A. Hypoxia stimulates osteopontin expression and proliferation of cultured vascular smooth muscle cells: potentiation by high glucose. Diabetes, 2001, 50(6), 1482-1490. [http://dx.doi.org/10.2337/diabetes.50.6.1482] [PMID: 11375351]

[32] Stamler, J.; Vaccaro, O.; Neaton, J.D.; Wentworth, D. Diabetes, other risk factors, and 12-yr cardiovascular mortality for men screened in the Multiple Risk Factor Intervention Trial. Diabet. Care, 1993, 16(2), 434-444. [http://dx.doi.org/10.2337/diacare.16.2.434] [PMID: 8432214]

[33] Ceriello, A.; Esposito, K.; Piconi, L.; Ihnat, M.A.; Thorpe, J.E.; Testa, R.; Boemi, M.; Giugliano, D. Oscillating glucose is more deleterious to endothelial function and oxidative stress than mean glucose in normal and type 2 diabetic patients. Diabetes, 2008, 57(5), $1349-1354$. [http://dx.doi.org/10.2337/db08-0063] [PMID: 18299315]

[34] Muggeo, M.; Zoppini, G.; Bonora, E.; Brun, E.; Bonadonna, R.C.; Moghetti, P.; Verlato, G. Fasting plasma glucose variability predicts 10year survival of type 2 diabetic patients: the Verona Diabetes Study. Diabet. Care, 2000, 23(1), 45-50. [http://dx.doi.org/10.2337/diacare.23.1.45] [PMID: 10857967]

[35] Risso, A.; Mercuri, F.; Quagliaro, L.; Damante, G.; Ceriello, A. Intermittent high glucose enhances apoptosis in human umbilical vein endothelial cells in culture. Am. J. Physiol. Endocrinol. Metab., 2001, 281(5), E924-E930. [PMID: 11595647]

[36] Chamras, H.; Ardashian, A.; Heber, D.; Glaspy, J.A. Fatty acid modulation of MCF-7 human breast cancer cell proliferation, apoptosis and differentiation. J. Nutr. Biochem., 2002, 13(12), 711-716. [http://dx.doi.org/10.1016/S0955-2863(02)00230-9] [PMID: 12550055]

[37] Chen, Z.Y.; Istfan, N.W. Docosahexaenoic acid is a potent inducer of apoptosis in HT-29 colon cancer cells. Prostagland. Leukot. Essent. Fatty Acids, 2000, 63(5), 301-308. [http://dx.doi.org/10.1054/plef.2000.0218] [PMID: 11090257]

[38] Calviello, G.; Palozza, P.; Maggiano, N.; Franceschelli, P.; Di Nicuolo, F.; Marcocci, M.E.; Bartoli, G.M. Effects of eicosapentaenoic and docosahexaenoic acids dietary supplementation on cell proliferation and apoptosis in rat colonic mucosa. Lipids, 1999, 34(Suppl.), S111. [http://dx.doi.org/10.1007/BF02562252] [PMID: 10419112]

[39] Calviello, G.; Palozza, P.; Maggiano, N.; Piccioni, E.; Franceschelli, P.; Frattucci, A.; Di Nicuolo, F.; Bartoli, G.M. Cell proliferation, differentiation, and apoptosis are modified by n-3 polyunsaturated fatty acids in normal colonic mucosa. Lipids, 1999, 34(6), 599-604. [http://dx.doi.org/10.1007/s11745-999-0404-6] [PMID: 10405974]

[40] Kim, H.J.; Vosseler, C.A.; Weber, P.C.; Erl, W. Docosahexaenoic acid induces apoptosis in proliferating human endothelial cells. J. Cell. Physiol., 2005, 204(3), 881-888

[http://dx.doi.org/10.1002/jcp.20351] [PMID: 15795939]

[41] Thompson, C.B. Apoptosis in the pathogenesis and treatment of disease. Science, 1995, 267(5203), 1456-1462. [http://dx.doi.org/10.1126/science.7878464] [PMID: 7878464]

[42] Slee, E.A.; Adrain, C.; Martin, S.J. Executioner caspase-3, -6, and -7 perform distinct, non-redundant roles during the demolition phase of apoptosis. J. Biol. Chem., 2001, 276(10), 7320-7326.

[http://dx.doi.org/10.1074/jbc.M008363200] [PMID: 11058599]

[43] Diep, Q.N.; Intengan, H.D.; Schiffrin, E.L. Endothelin-1 attenuates omega3 fatty acid-induced apoptosis by inhibition of caspase 3. Hypertension, 2000, 35(1 Pt 2), 287-291. [http://dx.doi.org/10.1161/01.HYP.35.1.287] [PMID: 10642312]

\section{(C) 2017 Rani and Aung.}

This is an open access article distributed under the terms of the Creative Commons Attribution 4.0 International Public License (CC-BY 4.0), a copy of which is available at: https://creativecommons.org/licenses/by/4.0/legalcode. This license permits unrestricted use, distribution, and reproduction in any medium, provided the original author and source are credited. 